\title{
Work ability and stress \\ in a bus transportation company in Belo Horizonte, Brazil
}

\author{
Avaliação da capacidade para o trabalho e estresse \\ em uma empresa de transporte coletivo de Belo H orizonte, Brasil
}

Rosana Ferreira Sampai ${ }^{1}$

Cecília M artins Coelho ${ }^{1}$

Fábio Bonfim Barbosa ${ }^{1}$

M arisa Cotta M ancini ${ }^{1}$

Verônica Franco Parreira ${ }^{1}$
${ }^{1}$ Department of Physical Therapy, School of Physical Education, Physical

Therapy and Occupational

Therapy, Federal University of M inas Gerais.

Av. Antônio Carlos 6627,

Pampulha. 31.270-010

Belo H orizonte M G.

rosana@netuno.lcc.ufmg.br
Abstract Demographic, occupational and psychosocial characteristics affect the health and occupational performance of workers. Theobjective of the present study was to elaborate a profile of the work ability and factors that affect it in a bustransportation company in Belo H orizonte, Brazil. Theinstruments used included a socio-demographic and occupational questionnaire, the Work Ability Index and the Job Stress Scale. Demographicinformation revealed that $85.7 \%$ of the 126 employees of the company were active workers, $98 \%$ weremales, with an average of 39 years of age $(S D=10)$ and 79 months working in the company $(S D=68)$; more than half reported having a low schooling level. In terms of personal habits, $88 \%$ were exposed to one or more risk factors, especially a sedentary lifestyle. Theaveragestrain value (asa consequence of stress) was $0.78(\mathrm{SD}=0.2)$ and $75.3 \%$ reported episodes of violence at the workplace. The work ability was good to excellent among $89 \%$ of the workers. Results from the logistic regression analysis showed that strain was the only significant variable in relation to theWork Ability Index, (estimated odds ratio of 0.02 ). The results suggest that psychosocial factors presented the greatest association with work ability, and preventive and/or corrective measures should be implemented.

Key words Occupational health, Work stress, Work ability, Motor vehicles
Resumo Características demográficas, ocupacionais e psicossociais afetam a saúde e o desempenho dos trabalhadores. 0 objetivo desteestudo foi elaborar um perfil da capacidade para o trabalho e fatores que a afetam em uma empresa de transporte coletivo de Belo Horizonte, Brasil. Os instrumentos utilizadosforam o Índice deCapacidade para oTrabalho, a Job Stress Scale e um questionário sociodemográfico e ocupacional. Dos 126 trabalhadores, $14,3 \%$ estavam aposentados ou afastados, todos por doença. Entre os ativos, a maioria era do sexo masculino (98\%), com idademédia de 39 anos ( $\mathrm{DP}=10$ ), baixa escolaridade (acima de $50 \%$ ) e tempo médio na empresa de 79 meses ( $D P=68$ ). Q uanto aos hábitos pessoais, $88 \%$ estavam expostos a um ou mais fatores de risco, em especial o sedentarismo. 0 valor médio de desgaste ( conseqüência do estresse) foi 0,78 ( $D P=0.2$ ) e 75,3\% relataram episódios de violência no trabalho. A capacidade para o trabalho foi boa ou ótima em $89 \%$ dos casos. N o modelo de regressão logística com variável resposta ICT, a única variável significativa foi o desgaste ( razão de chance estimada de 0,02 ). Os resultados sugerem que fatores psicossociais apresentaram maior associação com a capacidade para o trabalho e medidas preventivas e/ ou corretivas devem ser implementadas.

Palavras-chave Saúde do trabalhador, Índice de capacidade para o trabalho, Estresse ocupacional, Transporte coletivo 
Introduction

According to the 2000 demographic census $^{1}$, Belo H orizonte is one of the largest cities in Brazil, with around 2.2 million inhabitants. The city has a municipal fleet of 2.956 buses, which along with the 1.978 metropolitan buses ${ }^{2}$ transport about 34.3 million passengers per month ${ }^{3}$. In Belo H orizonte, theoperation of bustransportation has al ways been in thepower of privatebusiness initiatives, with the responsibility of system's planning and monitoring falling on the public power (Transport and Traffic Company of Belo Horizonte S/A-BHTrans).

The essential nature of quality transportation is widely known. This is true both in regards to infrastructure for productive processes and as a prerequisite for a good quality of life for the population. Despite this observation, bus transportation in large Brazilian urban centers presents serious organizational, material and security deficiencies. Such problems hinder the professional activities in this field, reduce the identification of employees with their job, and intensify the sensation of a loss of control regarding their functions, subjecting them to very arduous working conditions that affect health and generate stress ${ }^{3,4}$.

Occupational stress can be defined as "harmful physical and emotional responses that occur when job requirements do not match the capabilities, resources or need of theworker" ${ }^{5}$. If the cause of stress (stressor) is continuous or repetitive, the stress itself can become pathological. This situation can produce physical effects - cardiovascular disorders, obesity, asthma, peptic ulcers, rheumatoid arthritis - and psychological effects - cognitive symptoms (job dissatisfaction, difficulty in concentration), emotional symptoms (anxiety, anger, depression), somatic symptoms (headaches, perspiration, dizziness) and behavioral symptoms (use of alcohol and drugs, reduction in work performance, increasein levels of absenteeism or medical leave, increase in the number of on-the-job accidents and high personnel turnover). When the stressor is acute and intense, as in the case of assaults, the individual can present unpleasant or escapist symptoms related to situations that are similar to theinitial trauma and psychological conditions associated with anxiety, depression, thoughts of suicide, panic, anti-social personality, agoraphobia and substance abuse $\mathrm{e}^{6-8}$.

Currently, there are four dominant theoretical models on occupational stress ${ }^{7}$. Each theory explains important aspects regarding this type of stress, differing in the emphasis given to the as- pects of work environment or individual factors and personal strategies for dealing with problems. Despite the variation regarding emphasis, the theories arefor the most part complementary. In comparison with the other models, the demand-control/support model $(D C / S)^{9,10}$ has led the research on occupational stress in recent decades ${ }^{7,11,12}$. Be sides the strong empirical data, this model presents considerable validity in consideration of the work environment and has provided key elements for interventions in the main international policies on occupational stress. Furthermore, this model is capable of identifying work dimensions and is clearly based upon scientific evidence ${ }^{7}$. Its emphasis is on the work environment and the purpose of the model is to characterize strain ${ }^{13}$, which is considered a consequence of stress. The relation between strain and further risk for psychological and physical disorders has been demonstrated ${ }^{7}$. According to the DC/S model, strain results from the combined effects of high demand and low control at the workplace and is exacerbated by a low level of social support ${ }^{7,10,13}$.

Excessive demands and stress factors at work can trigger a functional aging of the worker, that is, they can generate an early loss of work ability ${ }^{14,15}$, which is defined as "how well a worker is in the present, or will be in thenear future, and how capablehe/shecan bein executing his/her work in function of the demands on his/her state of health, as well as his/her physical and mental capabilities"16. Besides being harnessed to the functional context and the socio-cognitive repertoire of the worker, studies have highlighted the relationship between work ability and worker's age (the older the age, the lower the work ability) ${ }^{17}$. Results from research in the field of health and work also suggest strong associations between the perception of the level of stress, lifestyle and a self-evaluation of health ${ }^{18,19}$. These factors, together with personal and occupational characteristics can influencethehealth, work ability, efficiency and productivity of the work$\mathrm{er}^{3,14,20-22}$. Good working conditions and a healthy lifestyle allow the maintenance of health and work ability throughout advanced age ${ }^{14}$. Therefore, a systemized assessment of work ability isneeded to identify possible agents associated with occupational symptoms, injuries, illnesses and stress ${ }^{14,17}$ so that preventativeand/or correctivemeasurescan beimplemented.

The aim of this study was to assess work ability and the factors that affect it, as well as the stress level of workers from a bus transportation company in the city of Belo H orizonte/Brazil. 


\section{Material and methods}

All the workers from a bus transportation company in Belo Horizonte participated in the study, grouped into three sectors: administration, maintenance and operation. The company is responsible for three bus lines in town and has a fleet of 23 vehicles.

An observational cross-sectional study was carried out. Data collection was divided into two steps. In the preliminary step, there was a collection of demographic and occupational data, as well as data related to employee health: gender, age, occupation, time at the company, averagesalary level, work shift, work situation (active, on leave or retired), illnesses reported by the workers (collected by the work security technician) and diagnosis of retired workers or those on leave in accordance with the International Statistical Classification of Disease and Related Health - 10th Revision (ICD-10) ${ }^{23}$.

Based on the preliminary information, assessment instruments were selected for the second step, consisting of three questionnaires and one open question, which madeavailableinformation on the general characteristics of the worker, occupational stress, work ability and complaints toward the company. In interviews with drivers and changemakers, further questions were added regarding violence in the workplace. All retired workers were excluded in the second step, as werethose on leave, on vacation or recent hired. Interviews were carried out on an individual basis following the consent of the interviewees, and conducted in locales that assured privacy and the confidentiality of the information. Oneexaminer was responsiblefor the application of two of the questionnaires. Another examiner was responsible for the third questionnaire and the open question. Data collection was carried out from October to February 2005.

The general characteristics of the employees included additional demographic data and personal habits. Smokers were considered those workers that reported smoking regardless of regularity or quantity. The consumption of more than 14 doses of alcoholic beverage per week and/or 5 doses on a single occasion was considered alcohol abuse ${ }^{18}$. The practice of regular physical activity was considered that with a minimum duration of 30 minutes and a frequency of at least three times per week.

Occupational stress was assessed through the Job Stress Scale (JSS), an instrument based on the DC/S model $9,10,14,24$. The instrument was adapted to Portuguese and tested on a Brazilian population $^{13}$. There is a total of 17 questions divided into three categories: psychological demand (five ques- tions); control or amplitude of decision-making, subdivided into intellectual discernment (four questions) and authority over decisions (two questions); and social support (six questions). Responses are presented on a Likert scale (scores 1 to 4). Job strain is obtained through the ratio between psychological demand and amplitude of decision-making, with the highest quartile (high demand and low control) considered exposure to a high degree of job $\operatorname{strain}^{10,13,25}$. Low scores in the category of social support also contribute to a high level of job strain ${ }^{10,13}$.

Work ability was assessed by means of theWork Ability Index (WAI). The WAI is an instrument adapted for the Brazilian population ${ }^{16}$ and utilized in other studies in the country ${ }^{14,17,21,26}$. The WAI is composed of 60 questions regarding personal aspects as well as physical and mental demands that are present in the workplace, along with questions on the health state of the worker. The instrument provides a final score that varies between 7 and 49 . The work ability and the objectives of any necessary measures to be taken are classified in the following manner: 7 to 27 points ( poor work ability restore ability); 28 to 36 points (moderate work ability - improve ability); 37 to 43 (good work ability - improve ability); and 44 to 49 points (excellent work ability - maintain ability). TheWAI is a reproducible instrument that can be used with an individual or with groups and can be utilized for follow-up ${ }^{16}$.

The literature has documented consistent psychometric propertiesfor theinstruments used. The WAI exhibited acceptable test-retest reliability index for classifying workers into categories (agree ment percentage of $66 \%)^{27}$. The JSS adapted to Portuguese demonstrated response stability in a test-retest study (intra-class correlation coefficients - ICC: 0.88 for the demand dimension, 0.87 for control and 0.86 for social support). Concerning the sub-dimensions, "authority in decision-making" had the lowest stability level (0.64), while the value for intellectual discernment was 0.87 . The values of internal consistence (Cronbach alpha coefficients) varied between 0.63 and $0.86^{13}$.

Complaints related to the company were obtained through an open question. The responses were grouped in accordance with the classification of the National Institute for Occupational Safety and $\mathrm{H}$ ealth $(\mathrm{NIOSH})^{5}$ in six broad categories re ferring to possible sources of stress at the workplace: task design, management style, interpersonal relationships, rules of work, concerns with career and environmental conditions. In the present study there was the need to add a category refer- 
ring to violence, as this is an issuethat is peculiar to Brazilian buscompanies. Violence was al so assessed through a question regarding previous episodes of assaults, physical aggression and/or verbal threats, as well as regarding the fear of the occurrence/reoccurrence of this type of event.

Descriptive analysis was carried out for all the variables studied. For measuring the association between variables, the chi-square test for nominal variables and the linear correlation for continuous variables were used. The Student's t-test was used for identifying differences between averages. A logistic regression model was used to test associations between work ability and the other variables. The logistic regression model was chosen considering that the dependent variable, WAI, was recodified into two categories (1-final WAI scoreless than or equal to 36; and 2-final WAI score greater than 36). This technique allowed the quantification of the degree of association between the de pendent variable and the other variables. The association index is called theodds ratio, which is the chance of the occurrence of a given work ability in function of an explicative variable in the presence of variables in the model. In the analyses, á $=0.05$ was adopted. The descriptive and inferential significance level of analyses was conducted with the Statistical Packagefor Social Sciences software, version 12.0 .

Results

Preliminary step

All employees were included in the first phase of the study and the results are presented on table 1. The company currently has 126 employees, among which $85.7 \%$ are active, $3.2 \%$ are retired and $11.1 \%$ are on leave for reasons of illness.
Among the active workers, the majority was male and just over half had up to 39 years of age (51.4\%). The drivers were the employees that presented the highest average age ( 45 years, $S D=10$ ). The operations sector united $79.6 \%$ of the workers $(n=86)$, themaintenance sector contained $12 \%$ and the administration sector $8.3 \%$. In an initial survey on illnesses reported by the employees, $100 \%$ of the activeworkers presented musculoskeletal complaints and $85 \%$ reported symptoms related to stress.

All of the retired workers were male, with an average age and time of service prior to retirement higher than the active workers. Following theICD$10^{23}$, one worker retired because of Circulatory System IIIness; one because of Osteomuscular and Conjunctive Tissuelllness; one because of Injuries, Poisoning and Other Consequences of External Causes; and another because of N ervous System Illness.

All the workers on leave were male, with an average age at the time of entering on leave also higher than theactiveworkers and an averagetime of service prior to going on leave lower than active workers. Following the ICD-1023, $64.3 \%$ of the workers on leave presented diagnoses of Diseases of the Musculoskeletal System and Connective Tissue and $\mathrm{M}$ ental and Behavioral Disorders.

\section{Second step}

Along with the 4 retired workers and 14 workers on leave, 2 employees that were on vacation and 1 that was hired during the time of the interviews were also excluded from the second step of thestudy, which then totaled a sample of 105 workers (83.3\%). Of the 105 employees, 100 showed up for the interviews, which represented a dropout rate of $4.8 \%$.

The general characteristics of the workers are presented on table2. Themajority of workers were

Table 1. Demographic and occupational data of the workers from a bus transportation company of Belo H orizonte/Brazil - results from the preliminary step.

\begin{tabular}{lrrr}
\hline & Active workers & Retired workers & Workers on leave \\
\hline Workers $(n)$ & 108 & 4 & 14 \\
M ale workers $(n)$ & 106 & 4 & 14 \\
Average age (years/SD) & $39(10)$ & $50(9)^{*}$ & $44(11)^{*}$ \\
Average time of service (years/SD) & $79(68)$ & $107 / 50^{* *}$ & $63(47)^{* *}$ \\
Average salary (R\$SD) & $687.22(252.16)^{* * *}$ & - & - \\
\hline
\end{tabular}

*At the time of retirement; ${ }^{* *}$ At the time of entering on leave; ** Approximately 250 U S dollars. 
married or lived with their companion, reported having up to 1 child ( $55 \%$ ) and low levels of schooling. Concerning personal habits, it was verified that thegreater part of theworkers (88\%) were exposed to one or more risk factor, with a special emphasis on a sedentary lifestyle.

Results concerning the JSS and WAI are also presented on table 2. Using the WAI, $89.3 \%$ of the individuals had good $(39.3 \%)$ or excellent $(50 \%)$ work ability. The operations sector presented an average score of $42.5(\mathrm{SD}=5.3$ ) at theWAI; maintenance presented an average score of $40.3(\mathrm{SD}=7.3$ ); and administration presented an average score of 41.3 (SD =6.1).

In reference to individual complaints, more than half of the workers ( $58 \%$ ) reported no negative factors related to the company. Among the remaining portion, $26.2 \%(n=11)$ stated violence at the workplace as the main complaint. This was followed by $19 \%(n=8)$ that reported aspects related to environmental conditions (unpleasant or dangerous physical conditions); $16.7 \%(n=7)$ reported difficulties in interpersonal relationships (poor social environment and lack of support or help from coworkers and supervisors); $16.7 \%$ $(n=7)$ demonstrated career concerns (job insecurity and lack of opportunity for growth, advancement, or promotion); $11.9 \%(n=5)$ criticized the design of tasks (unpleasant characteristics regarding working hours, breaks, shifts, bus lines, salary, and tasks that provide little sense of control); $4.8 \%$ $(n=2)$ mentioned difficulties regarding the work roles (conflicting or uncertain job expectations, too much responsibility); and 4.8\% ( $n=2)$ questioned the management style (lack of participation by workers in decision-making, poor communication in the organization).
Among the drivers and money collectors that participated in theinterviews, $75.3 \%$ reported having suffered some form of violence at the workplace, registering an average of 4.8 episodes ( $S D=5.7$ ), and $41.6 \%$ stated being constantly worried about the possibility of the occurrence or reoccurrence of such episodes.

Table 3 displays thelinear correction coefficients between some of the variables. Negative associations were found between WAI and job strain, be tween WAI and the demand category of the JSS, between the control category and job strain of the JSS, between the social support category and job strain of the JSS, and between the demand category and social support of the JSS. Positive associations werefound between the demand category and job strain of the JSS, and between the control category and social support of the JSS.

Sedentary lifestyle presented a tendency toward a negative association with theWAI (Fisher's Exact Test with a value of $p=0.068$ ), which suggests that a sedentary lifestyleis related to lower work ability. The other variables showed no significant association with theWAI.

The association between theWAI and the variables of job strain, age and sedentary lifestyle was tested in the logistic regression model. Thejob strain variable was selected for having a significant association with the final WAI score in the univariate analysis. The demand category of the JSS was not included, as it presented a positive correlation with job strain. Age is considered in the literature as an important factor in the determination of work ability $(16,17)$. Therefore, for its biological plausibility, age was included in the model. Sedentary lifestyle was also included for having presented a tendency toward association with the WAI. As a

Table 2. Demografic data, personal habits, occupational stress and work ability of active workers from a bus transportation company of Belo Horizonte/Brazil - results from the second step.

\begin{tabular}{lcr}
\hline & Percentage of workers & Average values (SD) \\
\hline Married or lived with their companion & 68 & - \\
Less than four years of schooling & 67 & - \\
Number of children & - & $1.8(1.8)$ \\
Consumption of cigarette & 24 & - \\
Alcoholic beverages & 25 & - \\
Sedentary lifestyle & 81 & - \\
Demand Category of Job Stress Scale & - & $11.6(2.5)$ \\
Control Category of Job Stress Scale & - & $15.3(2.7)$ \\
Social Support of Job Stress Scale & - & $19.9(3.7)$ \\
Strain of Job Stress Scale & - & $.78(.2)$ \\
Work Ability Index & - & $42.1(5.7)$ \\
\hline
\end{tabular}




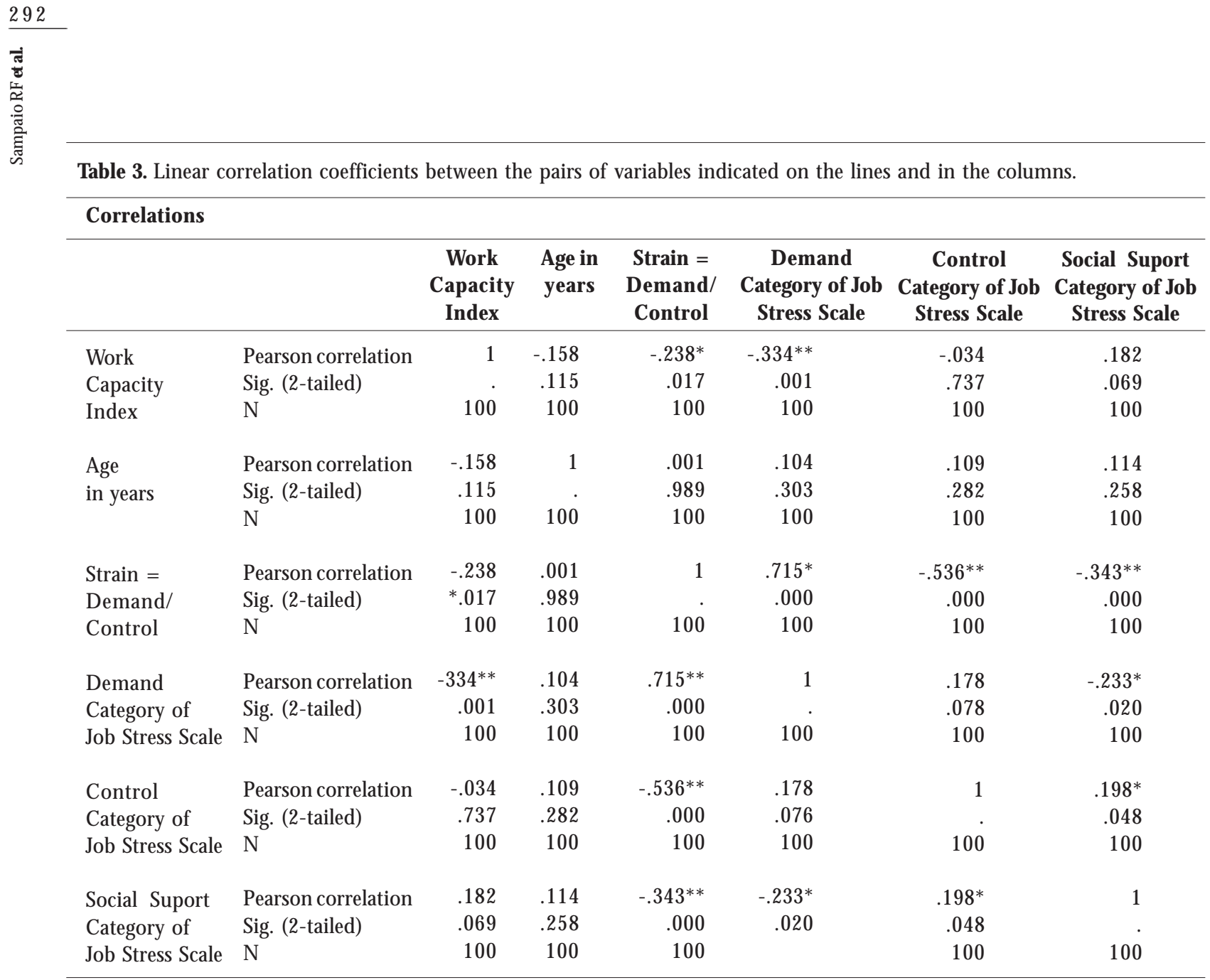

* Correlation is significant at the 0.05 level (2-tailed); ** Correlation is significant at the 0.01 level (2-tailed).

result, job strain was the only variable that proved significant, with an estimated odds ratio of 0.02 in relation to theWAI, that is, theincrease of 1 unit of job strain causes theWAI to be multiplied by 0.02 .

\section{Discussion}

Results from the present study reveal that the socio-demographic and occupational profile of the workers is similar to that of other studies. The predominance of male workers and the higher average age among the drivers was also reported in a recent study ${ }^{22}$. The older age of the drivers in relation to other workers could possibly be explained by the fact that their function requires more qualified and experienced workers. The average salary and low level of schooling are in accordance with the situation of bus drivers throughout Belo Horizonte and São Paulo ${ }^{3}$. Interviews carried out with 984 of the approximately 15.000 drivers of transportation companies of the metropolitan area of
Belo $\mathrm{H}$ orizonte indicated that there was the same predominance of male workers (99.8\%) and $76 \%$ of the workers had between 30 and 49 years of age, $68.8 \%$ had less than eight years of schooling and $58.6 \%$ lived with one or no child. The average salary was also similar to the present study $(\mathrm{R} \$ 689,00)^{28}$.

The most frequent complaints during the initial assessment of health conditions were musculoskeletal problems and stress, according to the self-reported illness pattern for bus transportation professionals $5^{3,22}$. According to the literature, aspects related to the health of bus drivers in Belo $\mathrm{H}$ orizonteare related to musculoskeletal problems, chronic headache, nervousness and depression, cardiovascular and gastrointestinal affections, eyes irritation and hearing reduction ${ }^{28}$. Improvements in work conditions have al ready been done, such as placement of the motor in the central or back part of the buses ${ }^{28,29}$, construction of a small room and toilet at the ends of lines, implantation of hydraulic direction, retractable steering wheels with 
height regulation, impact reduction and ergonomic comfort devices at the driver and money collector seats, development of projects aiming at assaults reduction ${ }^{28}$ and monitoring excessive muscle efforts on curves and brakes, and other technological equipments have also been acquired, such as fuel consumption and high velocity controllers, sonorous signals devices synchronized with luminoussigns and retardation, and informational and electronic systems to control the costs and manage the fleet of vehicles ${ }^{29}$.

From the results concerning problems related to the company, the high number of violent episodes merits particular attention. The direct consequence of this violence is evidenced by the fact that a large portion of the professionals in the operations sector report working with the constant fear or concern of being subjected to some type of coercion on the job. It should be highlighted that the reports of violent episodes at the present study refer only to those that occurred during the current job. Nonetheless, prior episodes of violence in all likelihood contribute toward the concern and fear during the day-to-day work.

An interview carried out with transportation company managers, administrative organs and unions showed that they did not consider spontaneously that the violence is a generator of problems at work. N evertheless, $43.3 \%$ of the drivers reported assaults using weapons inside the bus within the last year and $40.1 \%$ reported verbal aggressions. The majority of drivers reported fear of being assaulted, suffering accidents, dying, becoming ill and being dismissed ${ }^{28}$.

The present study did not take into account the differences of stressors among the bus lines and this may have influenced the results. The company rotates workers and has two lines that are considered to have problems. Oneline has a greater number of episodes of violenceand the other has a high number of passengers, which also triggers stress.

The negative factors related to environmental conditions, task design and rules of work can probably be explained by the peculiarities of the public urban transportation system. Issues such as such as noise and vibrations, as well as low levels of control over their tasks and little possibility of change ${ }^{12}$, simultaneity between production and consumption, irregular demands, geographic dispersion on not controlled environments, the possibility of being influenced by a variety of variables like topography, urban trajectory and traffic, the littledifferentiation in theserviceprovided, the context and the relation among users (demand), employers (offer) and the public power (regulation) ${ }^{29}$.
According to the literature, the great majority of the drivers havefixed schedules (77.6\%), among which $19.7 \%$ practicethe doubleshift on rush hours. This information indicates that $42 \%$ of the workers have unhealthy schedules ${ }^{28}$. The literature emphasizes work shift, timespent working at the function, workers' age and lifestyle as relevant factors in explaining the perception of the worker regarding his/her work ability ${ }^{17,21}$. In the present study, no association was found between work shift and the WAI. This was probably due to the fact that some workers frequently change shifts and lines.

The workers' time of service at the company was al so assessed, but had no influence on theWAI. $M$ any of the workers may haveperformed the same type of service prior to be contracted by the company in question. This possibility was not taken into account and may have generated such a result. However, a study carried out with 475 electric sector workers demonstrated a significant progressive decrease of the WAI associated to the increase of the time at the company ${ }^{30}$.

The age of the workers presented no significant correlation with theWAI, which is different to what is found in the literature ${ }^{16,30}$. In our results, the weak association may be attributed to the fact that the individuals with the greatest losses had al ready been removed from the work force, whether voluntarily or not (effect of healthy workers or of selection) ${ }^{14,15,31}$. Bellusci and Fischer ${ }^{14}$ found that just the 40 to 50-year age group presented a significant association between aging and a reduction in theWAI. The authors al so hypothesized the healthy worker effect to explain such a fact. For supplying an instantaneous image of the assessed relation, cross-sectional cohort studies such as this one can lead to theidentification of just the survivors of the effect under study (prevalencebias) and of its situation in regards to present exposure. This situation could lead to an underestimation of the degree of risk present in thework process, as themost affected do not remain on the job ${ }^{14}$. Furthermore, the cross-sectional cohort study renders impossible the establishment of the causal direction of the relations encountered ${ }^{15}$ and does not allow the prediction of how the health aspects will develop, nor how such aspects were prior to thestudy ${ }^{14}$. Despite these limitations, it has been the most used design in studies that investigated the relations between work ability and health at work, as well as between occupational stress and health at work ${ }^{15}$.

The fact that all the workers showed a good to excellent work ability, which was also observed in other studies that used the WAI ${ }^{27}$, can also be explained by the aforementioned healthy worker ef- 
fect. There is a need for longitudinal studies in order to elucidate the causal direction of the associations identified ${ }^{15}$ as well as to analyze possible changes for an effectiveintervention in the prevention of aspects that are harmful to health ${ }^{14}$. Both the WAI and the JSS are instruments that can and should be used in Iongitudinal studies with follow-up measures.

Despite other studies pointing out that a healthy lifestylecontributes toward maintaining health and work ability ${ }^{14,20,26,30}$, the risk factors of smoking, consumption of alcoholic beverages and the failure to practice physical activities showed no significant relation with the dependent variable. Only the practice of physical activities exhibited a tendency toward association with work ability in the present study. Thesefindings suggest that the practice of physical activity can contributeto the maintenanceof thework ability, in accordance with other study ${ }^{30}$. An unhealthy lifestylewas expected among the workers of the transportation sector ${ }^{22}$. Problems related to obesity can also be encountered among drivers, what can be explained by the characteristics of the job (mostly seated), stress, lack of time and location for adequate meal $\mathrm{s}^{28}$.

The elevated frequency of a sedentary lifestyleat the actual study can be due to the fact that the content of this type of report was not altogether socially acceptable, leading the workers to diminish the impact of their information ${ }^{7}$ and resulting in an unfaithful representation of the actual situation. Despite the weight of such considerations, studies havedemonstrated that data obtained from theselfreport measures provide important elements regarding health and working conditions $s^{3,7,11,17}$.

It has been demonstrated that there may be differences in work ability between occupational groups, which is possibly related to content and working conditions, as well as individual perceptions ${ }^{10}$. Furthermore, an investigation developed in celluloseand paper industry demonstrated that the particularities of the work process in each sector present an important influenceon theemergenceof ailments ${ }^{32}$. Thus, in the present study, we opted for the utilization of work sector variable instead of position or occupation at the company, considering that the employees assumed very distinct tasks. Such distinctions could have influenced the results and the sector variable presented no significant association with job strain or with the WAI.

There is strong evidence in the literature that occupational stressors are important factors leading to health problems among workers in bus transportation companies ${ }^{33}$. The negative association found between theWAI and the job strain variablesuggests that thestress factor is related to func- tional aging. Other investigations have verified that job strain in the work environment is associated with a greater risk of illness or injuries ${ }^{10,24}$, which in turn can generate a reduction in work ability. A negative association was also found between the WAI scoreand the demand category of the JSS, but no relation was found between the WAI and the control category. Araújo et al. ${ }^{31}$ observed that the psychological demands of work exercise more influence over the health of workers than control exercises over work.

In our study, we also found no association between theWAI and the support category of the JSS. Results from Araújo et al. ${ }^{31}$ demonstrated a significant association between this category and mental health, but according to the authors, social support did nothing to modify the association between job strain and mental health.

Among the approximately 26.000 workers of transportation companies of Belo Horizonte (including drivers, money collectors, mechanics and inspectors), 900 drivers reported stress as a common health problem ${ }^{28}$. In a random sample of 925 bus drivers and money collectors in the city of São Paulo there was a prevalence of $20.3 \%$ of minor psychiatric disorders ${ }^{34}$. The prevalence of stress among bank workers showed that $47 \%$ present any symptom typical of stress ${ }^{35}$ and a study regarding administrative workers reported a prevalence of strain in $14 \%$ of the workers ${ }^{36}$. The Psychosocial Working Conditions surveys in Great Britain indicates that $15.2 \%$ of workers find their job very or extremely stressful ${ }^{37}$. The differences encountered in stress prevalence may be due to the characteristics of the different occupational groupsstudied and the diversity of instruments used to classify stress.

In a cross-sectional study developed in a population of electric sector workers, the multipleanalyses adjusted for sex and time at company showed that the factors that better explained the variability of WAI were work stress and physical health. Excluding health dimensions, the factors that better explained the variability of WAI were work stress, local of work and lifestyle ${ }^{30}$. Another study involving administrative workers at the same city identified that time in job and job satisfaction were significantly associated to the WAI and physical and mental health were independently associated with the work ability ${ }^{38}$. Another study concerning physicians also indicated that stress negatively influenced WAI scores ${ }^{39}$.

As can be seen, an individual's response to environmental stressors is multi-factorial, undergoing influences from the characteristics of the stressor, biological factors, prior history of stressors 
and capacity to cope with stressful situations $s^{6,33}$. In a number of studies, one individual parameter, the Sense of Coherence ( $\mathrm{SOC}$ ), has been considered as important factor in the capacity of coping with stressors and in maintaining health ${ }^{25}$. It is also known that thefamily-work interferenceinfluences the occupational stress ${ }^{40}$, but these features were not assessed in the present study.

Studies regarding the transportation management with special focus on theorganization of work at the bus companies are scarce ${ }^{29}$. Some studies point out the importance of a holistic approach in the assessment of bus transportation workers due to the interaction between occupational and personal factors ${ }^{12}$. It is important to consider such issues in future investigations. Despite this observation, the isolated characteristics of the work exercise a strong influence over the health and productivity of workers and there is a considerable possibility of confronting problems through organizational interventions ${ }^{7,12,33}$.

In the work environment, it is important to seek solutions that maximize the balance between ability and demand. For such, it is necessary to establish flexibility in the tasks and identify specific requirements for promoting health among theworkers who have lost the functional ability for work. In several countries, the notion has been spread that a functional psychosocial environment in the workplace depends, in a large part, on an adequate organization of the work force ${ }^{10}$. Added to this is the importance of lifestyle and individual perceptions, which serve as motivational factors for the processes of organizational changes in thework ${ }^{10,14}$. It should also be assured that capability, experienceand autonomy regarding decision-making and opportunities for growth in the profession are fully utilized, thereby permitting the permanence of workers in their jobs and avoiding situations of temporary leave or early retirement due to an inability for work ${ }^{12,14,32}$.
Considering that in the present study all the workers demonstrated a good to excellent work ability, measures are recommended for improving or maintaining this ability. M oreover, theWAI presents questions on self-reported and diagnosed illnesses, but only the diagnosed illnesses are considered in the final score ${ }^{16}$. This does not seem to have been the case with the sample studied, but the selfreported illnesses could have perhaps interfered in the work ability of individuals, and thus, could be analyzed with greater attention.

Regarding the issue of violence in Brazil, the tremendous difficulty in controlling it is widely perceived. Direct confrontation with transgressors generates fear and panic, as well as increasing the risk of fatalities. Psychological consequences can emerge, with a negative influence on the health of the workers. Ther efore, measures for the recuperation of self-esteem and stress control should be instituted ${ }^{4}$, along with public policies for the reduction of violence 3 .

Based on the observations described herein and considering the importance of public transportation to the well-being of the entire community, we can conclude that it is necessary to implement broad and continuous preventative measures in the work environment, as well as establish an epidemiological monitoring of the physical and mental health of the professionals in this field $d^{3,33}$.

\section{Collaboration}

RF Sampaio, CM Coelho and FB Barbosa worked on the elaboration of the research project, data collection and analysis, and on the conception and writing of this paper. MC M ancini and VF Parreira worked on the final version of the paper.

\section{References}

1. Instituto Brasileiro de Geografia e Estatística. [homepage on the Internet]. População residente, por sexo e situação do domicílio, população residente de 10 anos ou mais de idade, total, alfabetizada e taxa de alfabetização, segundo os Municípios; 2000 [cited 2006 ] an 20]. Available from: http://www.ibge.gov.br/

2. Prefeitura Municipal de Belo Horizonte. [homepage on the Internet]. Características físico-operacionais do sistema de transporte coletivo; 2000 [cited 2006 Jan 20]. Available from: http://portal1.pbh.gov.br/pbh/ pgEDOCUM ENT_VisualizaConteudo_Header.html?query $=p_{-}$conteudo.id $=1687$ /
3. Costa LB, Koyama MAH, M inuci EG, Fischer FM. M orbidade declarada e condições de trabalho: 0 caso dos motoristas de São Paulo e Belo Horizonte. Sao Paulo Perspec 2003; 17(2):54-67.

4. Paes-M achado $E$, Levenstein C. Assaltantes a bordo: violência, insegurança e saúde no trabalho em transporte coletivo de Salvador, Bahia, Brasil. Cad Saúde Pública 2002; 18(5):1215-1227.

5. NIOSH [homepage on the Internet]. Stress at work. 1999 [cited 2005 Dec 4]. Available from: http://www. cdc.gov/niosh/stresswk.html/ 
6. Anisman $\mathrm{H}, \mathrm{M}$ erali $\mathrm{Z}$. Understanding stress: characteristics and caveats. Alcohol Res H ealth 1999; 23(4):241249.

7. Dollard M. Work stress theory and interventions: from evidence to policy. In: NOHSC symposium on the OHS implications of stress. M elbourne: University of South Australia; 2001.

8. Tansey TM, Mizelle N, Ferrin JM, Tschopp MK, Frain $M$. Work-related stress and the demand-control-support framework: implications for the P x E fit model. J Rehabil 2004; 70(3):34-41.

9. Theorell T, Perski A, Akerstedt T, Sigala F, AhlbergHultén G, Svensson J, Eneroth P. Changes in job strain in relation to changes in physiological state. Scand J Work Environ Health 1998; 14:189-196.

10. Theorell T. The demand-control-support model for studying health in relation to the work environment: an interactive model. In: Orth-Gomér K, Schneiderman $\mathrm{N}$, editors. Behavioral medicine approaches to cardiovascular disease prevention. M ahwah: Lawrence ErIbaum Associates; 1996. p. 69-85.

11. Gimeno D, Benavides FG, M ira M, M artinez JM, Benach J. External validation of psychological job demands in a bus driver sample. J O ccup Health 2004; 46:43-48.

12. Poulsen KB. The healthy bus project in Denmark: need for an action potential assessment. Health Promot Int 2004; 19(2):205-213.

13. Alves M GM, Chor D, Faerstein E, Lopes CS, Werneck GL. Versão resumida da "job stress scale": adaptação para o português. Rev. Saúde Pública 2004; 38(2):164171.

14. Bellusci SM, Fischer FM. Envelhecimento funcional e condições de trabalho em servidores forenses. Rev. Saúde Pública 1999; 33(6):602-609.

15. M artinez MC, Paraguay AIBB, Latorre M RDO. Relação entre satisfação com aspectos psicossociais e saúde dos trabalhadores. Rev. Saúde Pública 2004; 38(1):55-61.

16. Tuomi K, IImarinen J, Jahkola A, Katajarinne L, Tulkki A. Índice de capacidade para o trabalho. Helsinki: Instituto Finlandês de Saúde Ocupacional; 1997.

17. Walsh IAP, Corral S, Franco RN, Canetti EEF, Alem MER, Coury HJCG. Capacidade para o trabalho em indivíduos com lesões músculo-esqueléticas crônicas. Rev. Saúde Pública 2004; 38(2):149-156.

18. Barros MVG, Nahas MV. Comportamentos de risco, auto-avaliação do nível de saúde e percepção de estresse entre trabalhadores da indústria. Rev. Saúde Pública 2001; 35(6):554-563.

19. Noriega $M$, Gutiérrez $G, M$ éndez I, Pulido $M$. Las trabajadoras de la salud: vida, trabajo y trastornos mentales. Cad Saúde Pública 2004; 20(5):1361-1372.

20. Frone MR. Work stress and alcohol use. Alcohol Res $H$ ealth 1999; 23(4):284-291.

21. M etzner RJ, Fischer FM. Fadiga e capacidade para o trabalho em turnos fixos de doze horas. Rev. Saúde Pública 2001; 35(6):548-553.

22. O belenis V, Gedgaudiene D, Vasilavicius P. Working conditions and health of the employees of public bus and trolleybus transport in Lithuania. M edicina 2003; 39(11):1103-1109.

23. Brasil. M inistério da Saúde. Décima Revisão da Classificação Internacional de Doenças e de Problemas Re lacionados à Saúde [homepage on the Internet]. 1998 [cited 2005 Dec 4]. Available from: http://www.datasus. gov.br/cid10/cid10.htm/
24. Fischer FM, Oliveira DC, Nagai R, Teixeira LR, Junior $M L$, Latorre MRDO, Cooper SP. Job control, job demands, social support at work and health among adolescent workers. Rev. Saúde Pública 2005; 39(2):245-253.

25. Agardh EE, Ahlbom A, Andersson T, Efendic S, Grill V, Hallqvist J, Norman A, Ostenson CG. Work stress and low sense of coherence is associated with type 2 diabetes in middle-aged Swedish women. Diab Care 2003; 26(3):719-724.

26. Raffone AM, Hennington EA. Avaliação da capacidade funcional dos trabalhadores de enfermagem. Rev. Saúde Pública 2005; 39(4):669-676.

27. Zwart BCH, Frings-Dresen MHW, Duivenbooden JC. Test-retest reliability of the work ability index questionnaire. Occup M ed 2002; 52(4):177-181.

28. Fundação Seade. Diagnóstico das condições de saúde e segurança dos motoristas de veículos automotores de transporte coletivo urbano na região metropolitana de Belo H orizonte. São Paulo: Fundação Seade; 2002.

29. Cruz MVG. Produção do serviço de transporte público urbano por ônibus: aspectos da organização do trabalho. RAC 1998; 2(3):45-65.

30. M artinez MC. Estudo dos fatores associados à capacidade para o trabalho em trabalhadores do setor elétrico [tese]. São Paulo (SP): Faculdade de Saúde Pública; 2006.

31. Araújo TM, Graça CC, Araújo E. Estresse ocupacional e saúde: contribuições do modelo demanda-controle. Cienc Saude Colet 2003; 8(4):991-1003.

32. Fassa AG, Facchini LA, Dall'Agnol MM. Trabalho e morbidade comum em indústria de celulose e papel: um perfil segundo setor. Cad Saúde Pública 1996; 12(3):297-307.

33. Kompier MA, Aust B, Van Den Berg AM, Siegrist J. Stress prevention in bus drivers: evaluation of 13 natural experiments. J O ccup H ealth Psychol 2000; 5(1):1131.

34. Souza M FM, da Silva GR. Risco de distúrbios psiquiátricos menores em área metropolitana na região Sudeste do Brasil. Rev. Saúde Pública 1998; 32(1):50-58.

35. Koltermann ITAP. Prevalência do estresse ocupacional em trabalhadores bancários [dissertação]. Pelotas (RS): Universidade Católica de Pelotas; 2005.

36. Macedo LET. Estresse no trabalho, problemas de saúde e interrupção de atividades cotidianas: associação no estudo pró-saúde [dissertação]. Rio de Janeiro (RJ): Escola Nacional de Saúde Pública Sérgio Arouca/Fundação Oswaldo Cruz; 2005.

37. Health and Safety Executive. Psychosocial working conditions in Great Britain in 2005. Sudbury: HSE Books; 2005.

38. Martinez M C, Latorre M RDO. Saúde e capacidade para o trabalho em trabalhadores da área administrativa. Rev. Saúde Pública 2006; 40(5):851-858.

39. Franjiæ N, M aleš-Biliæ L, Beganliæ A, M ustajbegoviæ J. Mobbing, stress, and work ability index among physicians in Bosnia and Herzegovina: survey study. Croat Med J 2006; 47:750-758.

40. Paschoal T, Tamayo A. Impacto dos valores laborais e da interferência família-trabalho no estresse ocupacional. Psic: Teor e Pesq 2005; 21(2):173-180.

Artigo apresentado em 16/11/2006

Aprovado em 27/07/2007 